\title{
The evidence of mtDNA haplogroup $F$ in a European population and its ethnohistoric implications
}

\author{
Helle-Viivi Tolk ${ }^{1}$, Lovorka Barac ${ }^{2}$, Marijana Pericic ${ }^{2}$, Irena Martinovic Klaric ${ }^{2}$, \\ Branka Janicijevic $^{2}$, Harry Campbell ${ }^{3}$, Igor Rudan ${ }^{3,4}$, Toomas Kivisild ${ }^{1}$, Richard Villems ${ }^{1}$ and \\ Pavao Rudan*,2
}

\begin{abstract}
${ }^{1}$ Department of Evolutionary Biology, Institute for Molecular and Cell Biology, University of Tartu, Riia 23, 51010 Tartu, Estonia; ${ }^{2}$ Institute for Anthropological Research, Amruseva 8, 10000 Zagreb, Croatia; ${ }^{3}$ Department of Public Health Sciences, The University of Edinburgh Medical School, Teviot Place, Edinburgh EH8 9AG, Scotland, UK; ${ }^{4}$ School of Public Health "Andrija Stampar", University Medical School, Rockefellerova 4, 10000 Zagreb, Croatia
\end{abstract}

Mitochondrial DNA polymorphism was analysed in a sample of 108 Croatians from the Adriatic Island isolate of Hvar. Besides typically European varieties of human maternal lineages, haplogroup $F$ was found in a considerable frequency (8.3\%). This haplogroup is most frequent in southeast Asia but has not been reported before in Europe. The genealogical analysis of haplogroup F cases from Hvar suggested founder effect. Subsequent field work was undertaken to sample and analyse $\mathbf{3 3 6}$ persons from three neighbouring islands (Brac, Korcula and Krk) and $\mathbf{3 7 9}$ more persons from all Croatian mainland counties and to determine if haplogroup $\mathrm{F}$ is present in the general population. Only one more case was found in one of the mainland cities, with no known ancestors from Hvar Island. The first published phylogenetic analysis of haplogroup $F$ worldwide is presented, applying the median network method, suggesting several scenarios how this maternal lineage may have been added to the Croatian mtDNA pool. European Journal of Human Genetics (2001) 9, 717-723.

Keywords: mtDNA; haplogroup F; Europeans; Croatians; isolate populations; phylogenetic analysis

\section{Introduction}

Maternally inherited mitochondrial DNA (mtDNA) and paternally inherited $\mathrm{Y}$ chromosome polymorphisms have been studied extensively as a powerful tool to understand the demographic history of human populations. It became apparent that large continental areas such as western, eastern and southern Eurasia differ profoundly in their mtDNA variety ${ }^{1,2}$ with only limited zones of admixture, eg in Central Asia. ${ }^{3}$ Thus, the major eastern Eurasian-specific mtDNA haplogroups A, B, F and $\mathrm{M}$ are only rarely found among western Eurasian popula-

*Correspondence: Prof Dr Pavao Rudan, MD, PhD, Director, Institute for Anthropological Research, Amruseva 8, 10000 Zagreb, Croatia.

Tel: ++385 14816 903; Fax: ++385 14813 777;

E-mail: pavao.rudan@luka.inantro.hr

Received 24 April 2001; revised 28 June 2001; accepted 29 June 2001 tions $^{4-12}$ whereas the dominant European haplogroup $\mathrm{H}$ is virtually absent in China and Japan. ${ }^{13,14}$ Hence, any deviation from this general finding deserves special attention as it may prove to be particularly informative.

A recent study of mtDNA haplogroups in four Croatian island isolates found a considerable frequency $(8.3 \%)$ of haplogroup $\mathrm{F}$ in the population of Hvar Island. ${ }^{15}$ This haplogroup, initially defined by the loss of HincII site at nucleotide position (np) $12406,{ }^{4,16}$ is common in populations of Central $^{3}$ and eastern Asia ${ }^{4,13,14,16-18}$ and to the best of our knowledge has never been reported in Europe. The aim of this study was to investigate the likely origin of this haplogroup in Hvar, to classify it within the phylogenetic tree of haplogroup $\mathrm{F}$ cases found worldwide and to discuss the ethnohistoric implications of this finding. 


\section{Materials and methods}

All blood samples were collected after obtaining informed consent. Details of sampling design and molecular analysis have been described previously. ${ }^{15}$ In the initial sample of 108 persons from six villages (Dol, Vrbanj, Svirce, Zastrazisce, Gdinj, Bogomolje) of the Croatian island Hvar, the hypervariable segment I (HVS-I) of the control region of mtDNA was PCR-amplified, followed by sequencing of the segment between nps 16024 and 16383 on ABI 377 DNA Sequencer (Perkin-Elmer) using the DYEnamic $^{(i x}$ ET terminator cycle sequencing premix kit (Amersham Pharmacia Biotech). In addition, a total of 379 individuals from all counties of Croatian mainland and 336 from Croatian islands Krk, Brac and Korcula were screened for the presence of haplogroup F by HVS-I and RFLP-typing.

The presence of haplogroup $\mathrm{F}$ was also checked from the following dataset: 5608 Europeans, ${ }^{19-23} 1582$ Near East and Caucasus individuals, ${ }^{12,21} 205$ Central Asians, ${ }^{3} 1008$ Indians $^{24}$ (and R Villems, personal communication) and 835 Eastern Asians ${ }^{13,14,17,18,25,26}$ (and R Villems, personal communication).

To confirm the exact haplogroup affiliation of mtDNA HVS-I lineages, a set of RLFP sites, diagnostic for main Eurasian haplogroups $^{4-7,10}$ were typed: 73 Alw44I, 1715 DdeI, 4577 NlaIII, 7025 AluI, 8249 AvaII, 9052 HaeII, 10028 AluI, 10394 DdeI, 10397 AluI, 12308 HinfI, 12406 HincII, 13366 BamHI, 13704 BstOI, 14465 AccI, 14766 MseI, 15606 AluI, 15904 MseI, following the previously established phylogenetic structure of Eurasian mtDNA lineages and haplogroups. ${ }^{7,9,10,12,21}$ In this work haplogroup is defined as a monophyletic clade in the mtDNA tree, comprising a group of haplotypes descending from the most recent common ancestor, as inferred from the shared mutations. ${ }^{27}$ We use informal terms for the hierarchy of the branching order of the phylogenetic tree as follows: limb $>$ bough $>$ twig. Mutations in mtDNA are numbered according to the Cambridge Reference Sequence (CRS). ${ }^{28,29}$

To specify the phylogenetic relationships between haplotypes, median-joining networks ${ }^{30}$ were constructed for the total sample set of Hvar mtDNAs and for the haplogroup F subclades F1a (HVS-I main motif: 16172, 16304) and F1b (HVS-I main motif: 16189, 16304), combining both D-loop and RLFP polymorphism data. The median network approach is useful in the case of high mutation rate, which causes many parallel mutations in phylogenetically distant branches, since it permits simultaneous revealing of a large number of equally parsimonious phylogenetic trees. Coalescence age of haplogroup $\mathrm{F}$ was calculated as described by Forster et $a l^{31}$ Because the founder effect was suspected, for nine haplogroup $\mathrm{F}$ subjects found on Hvar island the genealogies were reconstructed to include five generations, based on Parish registries.

\section{Results}

Maternal lineages found among the Hvar people are typical for a European population (Table 1). Figure 1 shows the reduced median network tree of mtDNAs from 108 individuals from Hvar population. The topology of the tree as well as the distribution of the frequencies of the mtDNA haplogroups ${ }^{15}$ do not differ substantially from that expected for a European Mediterranean population ${ }^{7,32}$ - except for the presence of haplogroup $\mathrm{F}$ at a frequency about $8 \%$. As mentioned above, haplogroup $\mathrm{F}$ must be very rare in European populations because it was not reported in largest recent collections $(n>5000)$ of mtDNA varieties. ${ }^{19-23}$ Therefore, its finding in Hvar was intriguing. Figure 2 shows the location of Hvar Island and its villages, along with reconstructed genealogies of nine haplogroup F cases. Moreover, it is worth noting that a subject indicated by two asterisks developed an additional mutation at np 16207 over a span of the four generations from the common ancestor.

The two competing hypotheses were that the haplogroup $\mathrm{F}$ was introduced to the island from an unidentified source population by sea or from the nearby mainland. The nine subjects with haplogroup F came from three different villages (Vrbanj, Svirce and Bogomolje). The reconstruction of genealogies to five generations linked these persons to three female ancestors (Figure 2). It failed to link them to a single ancestor since Parish registry records revealed that the female (indicated by an asterisk) immigrated to the island from the nearby mainland city of Podgora. On interview, this individual stated that her ancestors had arrived from within the Balkans mainland a few centuries ago. This implies that haplogroup $\mathrm{F}$ might be present in the Croatian general population. Subsequent field work was undertaken and 715 unrelated mtDNA genomes from all Croatian counties were analysed. One subject $(0.26 \%)$ from the northern part of Croatia (Zagreb county), was found to have the haplogroup $\mathrm{F}$ and was unaware of any ancestors from Hvar Island. Out of the 336 individuals from three other Eastern Adriatic islands (Krk, Brac and Korcula) no one had haplogroup F.

Haplogroup $\mathrm{F}$ derives from an internal node $\mathrm{R}$ of the human mtDNA phylogenetic tree ${ }^{10}$ and is a sister group to an eastern Eurasian haplogroup B, as well as to haplogroups H, J, $\mathrm{K}, \mathrm{T}$ and $\mathrm{U}$; the latter five comprising about $95 \%$ of the European mtDNA diversity. ${ }^{5-7}$ In order to obtain further insight into the origin of the 'Croatian F' lineages, we constructed a phylogenetic network from HVS-I haplotypes belonging to mtDNA haplogroup $\mathrm{F}$ which were published in the literature. Two main boughs of the subset of the limb F1, F1a and F1b, are depicted in Figure 3.

Haplogroup $\mathrm{F}$ is characteristic of the Chinese population $(10.8 \%)$ and reaches the highest frequency in the Vietnamese population $(32 \%){ }^{13,14,16,26}$ It is relatively frequent also among Mongolians (8.7\%), Koreans (5.1\%) and Japanese $(5.1 \%),{ }^{13,17}$ but very rare in northeastern Asians. ${ }^{33,34}$ The sample from three Turkic-speaking Central Asian populations $^{3}$ comprises 11 likely (based on HVR-I sequence 
Table 1 mtDNA variation among 108 individuals from the Croatian island Hvar

\begin{tabular}{|c|c|c|c|c|c|c|c|c|c|c|c|c|c|c|c|c|c|c|}
\hline $\begin{array}{l}\text { Haplo- } \\
\text { group }^{a}\end{array}$ & HVS-I sequence types ${ }^{b}$ & $\begin{array}{l}7 \\
3\end{array}$ & $\begin{array}{l}1 \\
7 \\
1 \\
5 \\
c\end{array}$ & $\begin{array}{l}4 \\
5 \\
7 \\
7 \\
9\end{array}$ & $\begin{array}{l}7 \\
0 \\
2 \\
5 \\
a\end{array}$ & $\begin{array}{l}8 \\
2 \\
4 \\
9 \\
b\end{array}$ & $\begin{array}{l}9 \\
0 \\
5 \\
2 \\
n\end{array}$ & $\begin{array}{c}\text { RLF } \\
1 \\
0 \\
0 \\
2 \\
8 \\
a\end{array}$ & $\begin{array}{c}\text { site } \\
1 \\
0 \\
3 \\
9 \\
4 \\
c\end{array}$ & $\begin{array}{c}\text { aria } \\
1 \\
0 \\
3 \\
9 \\
7 \\
a\end{array}$ & $\begin{array}{c}n^{c} \\
1 \\
2 \\
3 \\
0 \\
8 \\
g\end{array}$ & $\begin{array}{l}1 \\
2 \\
4 \\
0 \\
6 \\
0\end{array}$ & $\begin{array}{c}1 \\
3 \\
3 \\
6 \\
6 \\
m\end{array}$ & $\begin{array}{l}1 \\
3 \\
7 \\
0 \\
4 \\
P\end{array}$ & $\begin{array}{l}1 \\
4 \\
4 \\
6 \\
5 \\
5\end{array}$ & $\begin{array}{l}1 \\
5 \\
6 \\
0 \\
6 \\
A\end{array}$ & $\begin{array}{l}1 \\
5 \\
9 \\
0 \\
4 \\
u\end{array}$ & Total \\
\hline $\mathrm{F}$ & 189207 232A 249304311 & G & + & + & + & - & + & - & - & - & - & - & - & + & & - & & 1 \\
\hline $\mathrm{F}$ & 189 232A 249304311 & G & + & + & + & - & + & - & - & - & - & - & - & + & & - & & 7 \\
\hline $\mathrm{F}$ & 189 232A 249304311 & G & + & + & + & - & + & - & - & - & - & - & - & + & & + & & 1 \\
\hline $\mathrm{H}$ & 129264311 & A & + & + & - & - & + & - & - & - & - & & - & + & & - & & 1 \\
\hline $\mathrm{H}$ & 158 & A & + & + & - & - & + & - & - & - & - & & - & + & & - & & 1 \\
\hline $\mathrm{H}$ & 189 & A & + & + & - & - & + & - & - & - & - & & - & + & & - & & 2 \\
\hline $\mathrm{H}$ & 189 & & + & + & - & - & + & - & - & - & - & & - & + & & - & & 1 \\
\hline $\mathrm{H}$ & 189304 & A & + & + & - & - & + & - & - & - & - & & - & + & & - & & 1 \\
\hline $\mathrm{H}$ & 224 & & + & + & - & - & + & - & - & - & - & & - & + & & - & & 1 \\
\hline $\mathrm{H}$ & 235 & A & + & + & - & - & + & - & - & - & - & & - & + & & - & & 1 \\
\hline $\mathrm{H}$ & 241311 & A & + & + & - & - & + & - & - & - & - & & - & + & & - & & 1 \\
\hline $\mathrm{H}$ & 287 & A & + & + & - & - & + & - & - & - & - & & - & + & & - & & 1 \\
\hline $\mathrm{H}$ & 293311 & A & + & + & - & - & + & - & - & - & - & & - & + & & - & & 1 \\
\hline $\mathrm{H}$ & 304 & & + & + & - & - & + & - & - & - & - & & - & + & & - & & 3 \\
\hline $\mathrm{H}$ & 354 & A & + & + & - & - & + & - & - & - & - & & - & + & & - & & 3 \\
\hline $\mathrm{H}$ & 368 & A & + & + & - & - & + & - & - & - & - & + & - & + & & - & & 1 \\
\hline $\mathrm{H}$ & 93 & G & + & + & - & - & + & - & - & - & - & & - & + & & - & & 1 \\
\hline $\mathrm{H}$ & 93212222 & A & + & + & - & - & + & - & - & - & - & + & - & + & & - & & 2 \\
\hline $\mathrm{H}$ & 93260311 & A & + & + & - & - & + & - & - & - & - & & - & + & & - & & 1 \\
\hline $\mathrm{H}$ & 93265 & A & + & + & - & - & + & - & - & - & - & & - & + & & - & & 2 \\
\hline $\mathrm{H}$ & CRS & A & + & + & - & - & + & - & - & - & - & & - & + & & - & & 5 \\
\hline $\mathrm{H}$ & CRS & A & + & + & - & + & + & - & - & - & - & & - & + & & - & & 1 \\
\hline I & 129174189223311 & G & - & + & + & + & + & + & + & - & - & + & - & + & & - & & 1 \\
\hline I & 129148223 & G & - & + & + & + & + & + & + & - & - & & - & & & - & & 1 \\
\hline J & 69126145172261 & G & + & + & + & - & + & - & + & - & - & & - & - & & - & & 2 \\
\hline j & 69126145222 & G & + & + & + & - & + & - & + & - & - & & - & - & & - & & 4 \\
\hline j & 69126145261 & G & + & + & + & - & + & - & + & - & - & & - & - & & - & & 1 \\
\hline j & 69126172189 & G & + & + & + & - & + & - & + & - & - & & - & - & & - & & 1 \\
\hline j & 6993126 & G & + & + & + & - & + & - & + & - & - & & - & - & & - & & 2 \\
\hline K & 224304311 & G & + & + & + & - & - & - & + & - & + & & - & + & & - & & 1 \\
\hline $\mathrm{K}$ & 224311 & G & + & + & + & - & - & - & + & - & + & & - & + & & - & & 3 \\
\hline $\mathrm{T}$ & 126147169294296304 & G & + & + & & - & + & - & - & - & - & & + & + & & - & & 1 \\
\hline $\mathrm{T}$ & 126163186189192248266271294 & G & + & + & + & - & + & - & - & - & - & & & + & & + & & 1 \\
\hline $\mathrm{T}$ & 126163186189292294 & G & + & + & + & - & + & - & - & - & - & & + & + & & + & & 1 \\
\hline $\mathrm{T}$ & 126189294296298 & G & + & + & + & - & + & - & - & - & - & & + & + & & + & & 7 \\
\hline $\mathrm{T}$ & 126189223294296298299 & G & + & + & + & & & - & - & - & - & & & + & & + & & 1 \\
\hline $\mathrm{T}$ & 126189294296324362 & G & + & + & + & - & + & - & - & - & - & & + & + & & + & & 1 \\
\hline $\mathrm{T}$ & 126294296304 & G & + & + & + & - & + & - & - & - & - & & + & + & & + & & 3 \\
\hline U & 111192256270 & G & + & + & + & - & + & + & - & - & + & & - & + & & & & 1 \\
\hline $\mathrm{U}$ & 189270 & G & + & + & + & - & + & - & - & - & + & & - & + & & - & & 9 \\
\hline U & 192256270 & G & + & + & + & - & + & - & - & - & + & & - & + & & - & & 1 \\
\hline U & 192256270287320 & G & + & + & + & - & + & - & - & - & + & & - & + & & - & & 1 \\
\hline U & 192256270320 & G & + & + & + & - & + & - & - & - & + & & - & + & & - & & 1 \\
\hline U & 192270304 & G & + & + & + & - & + & - & - & - & + & & - & + & & - & & 1 \\
\hline $\mathrm{U}$ & 256270 & G & + & + & + & - & + & - & - & - & + & & - & + & & - & & 2 \\
\hline U & 51 129G 189256362 & G & + & + & + & - & + & - & - & - & + & & - & + & & - & & 5 \\
\hline $\mathrm{U}$ & 93356 & G & + & + & + & - & + & - & - & - & + & & - & + & & - & & 1 \\
\hline V & 298 & A & + & - & + & - & + & - & - & - & - & & - & + & & - & + & 3 \\
\hline V & 298311 & A & + & - & + & - & + & - & - & - & - & & - & + & & - & + & 2 \\
\hline preV & 298 & $A$ & + & + & + & - & + & - & - & - & - & & - & + & & - & + & 1 \\
\hline preV & 298311 & A & + & + & + & - & + & - & - & - & - & & - & + & & - & + & 1 \\
\hline W & 223292311 & $\mathrm{G}$ & + & + & + & + & + & - & - & - & - & & - & + & & - & & 2 \\
\hline HV & 311 & A & + & + & + & - & + & - & - & - & - & & - & + & & - & & 5 \\
\hline$x$ & 129189223278 & G & - & + & + & - & + & - & - & - & - & & - & - & + & - & & 1 \\
\hline $\mathrm{x}$ & 189223278299 & G & - & + & + & - & + & - & - & - & - & & - & - & + & - & & 1 \\
\hline
\end{tabular}

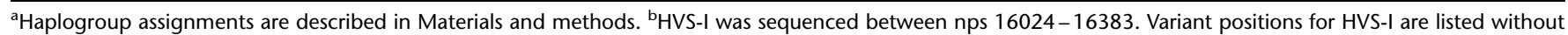
prefix 16000 according to the revised Cambridge Reference Sequence ${ }^{29}$; sequences identical to the latter are designated as CRS. For transitions only nucleotide positions are shown; for transversions the corresponding nucleotide is specified. Length variation in the C-stretch within nps $16184-16193$ and related A to $\mathrm{C}$ transversions at nps 16182 and 16183 are disregarded. 'Abbreviations for restriction endonucleases: a=Alul, b=Avall, c=Ddel, g=Hinfl, m=BamHI, n=Haell, o=Hincll, $\mathrm{p}=B s t \mathrm{OI}, \mathrm{q}=$ NlallI, $\mathrm{s}=A c \mathrm{cl}, \mathrm{u}=$ Msel. Gain or loss of a site is indicated by plus or minus, respectively. For $\mathrm{np} 00073$, respective nucleotide is indicated. 


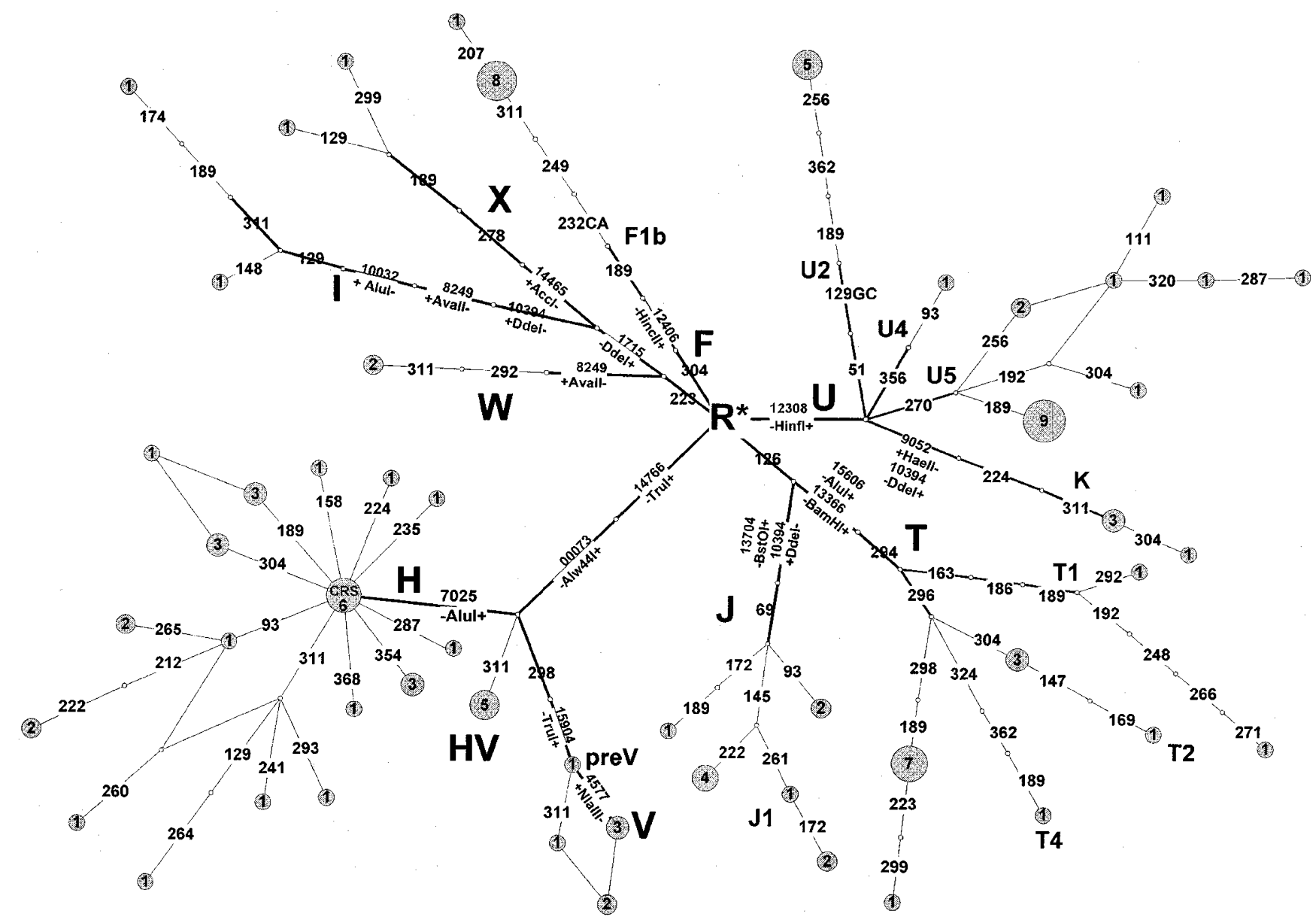

Figure 1 Median-joining network showing the phylogenetic relationship of mtDNA haplotypes detected in Hvar Island, Croatia $(n=108)$. Nodes represent haplotypes grouped into haplogroups indicated with alphabetical letters (see also Table 1). Each link represents one mutational event in mtDNA HVS-I (prefix 16000 is omitted) or regions covered with RFLP typing. The internal structure of the network relating established mtDNA haplogroups is shown in bold links. Reticulations reflect ambiguities caused by incompatible characters. Haplotype frequencies are shown inside node areas.

information only) individuals, carrying haplogroup $\mathrm{F}$ mtDNA genomes $(5.4 \%)$ and the corresponding mtDNA varieties originate from different limbs of haplogroup F. In a total sample of European, Near Eastern, Anatolian and South Caucasian data $(n=7190)^{12,19-23}$ only three individuals (0.04\%) had a haplogroup F: two Turks and one Azeri (Figure 3).

Figure 3 indicates that within the phylogeny of limb F1, the particular varieties found in Croatia, belong to a monophyletic clade within bough $\mathrm{F} 1 \mathrm{~b}$, specified by a rare $\mathrm{C}$ to $\mathrm{A}$ transversion at np 16232 and a transition at np 16249. The internal node is shared by Croats, Mongols and Turkicspeaking Uighurs, Kazakhs, Turks and even by one South Asian (Sri Lankan, our unpublished results) mtDNA. A further extension of this bough via additional transitions at nps 16129 and 16344 leads to a twig, shared by Korean and
Japanese $\mathrm{e}^{13,14,18}$ populations, including Ainus and Ryukyu people. Yet another twig (np 16172) is occupied by mtDNAs, found among Koreans and Turkic-speaking Uighurs. ${ }^{3,13}$ The single haplotype found in Croatian mainland belongs there as well (Figure 3). Considering all the available data, the coalescence age estimate for the base node of haplogroup $\mathrm{F}$ is approximately $40000-50000$ years before present, which agrees with an early Upper Palaeolithic origin of this major eastern Eurasian variety of mtDNA. However, it does not imply that the node containing Croatian mtDNAs started to expand at that time period. Bearing in mind a limited divergence of the corresponding internal node comprising Croatian haplogroup $\mathrm{F}$ sequences, it may have happened much more recently. More importantly, its phylogeography suggests that the particular variety of maternal lineages must have been within a migrational wave(s), carrying haplogroup 

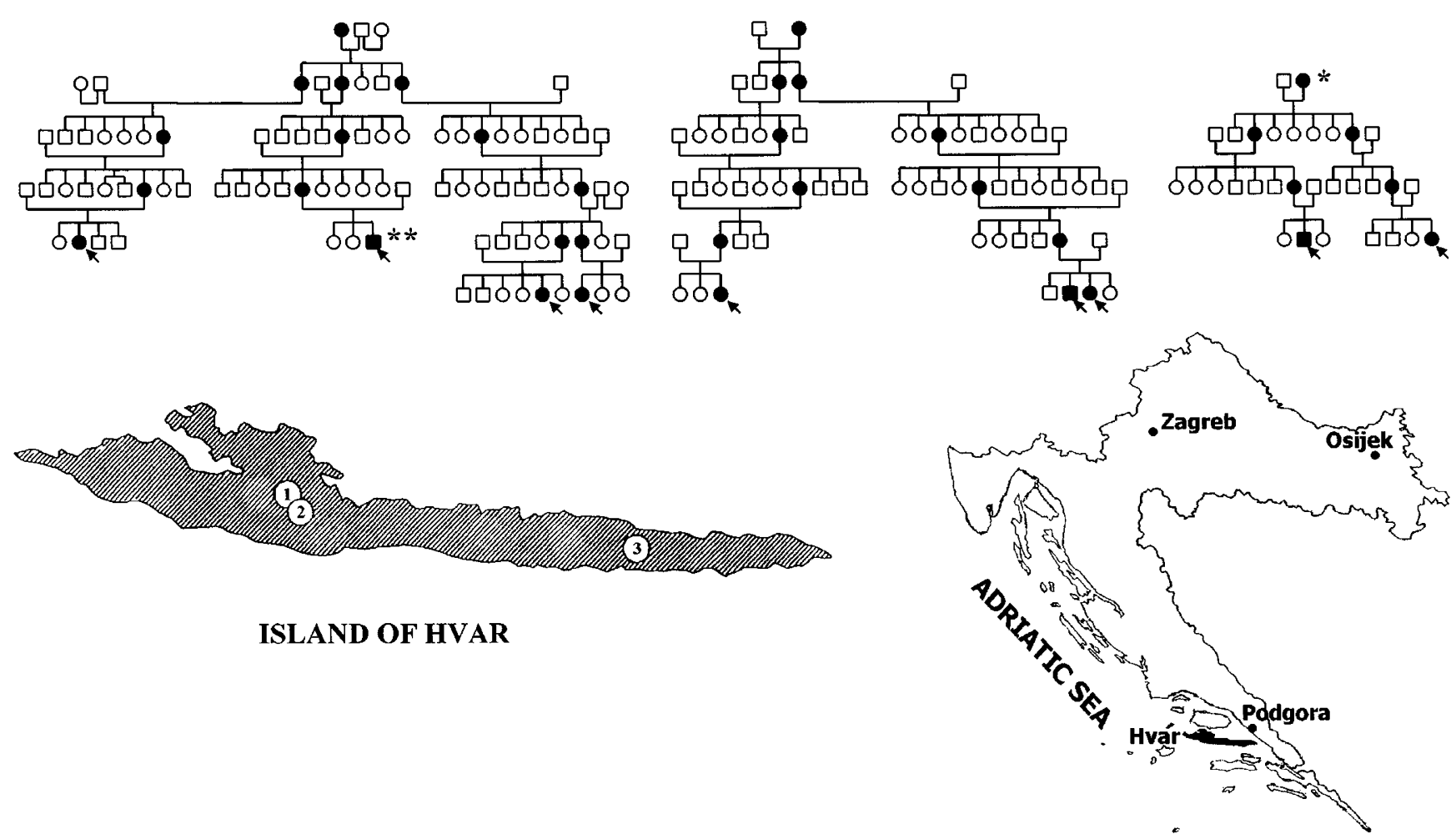

Figure 2 Geographic location of the Croatian subjects with haplogroup F and the reconstruction of the genealogies of Hvar Island cases originating from three villages ( $1=$ Vrbanj; $2=$ Svirce; $3=$ Bogomolje).

F north and westwards from its putative origin in southeastern Asia.

\section{Discussion}

In many European populations up to $1-2 \%$ of mtDNA lineages cannot be attributed to any European founder haplogroups. ${ }^{21}$ The high frequency $(8.3 \%)$ of haplogroup $\mathrm{F}$ in Hvar is likely the result of the founder effect in this small island population, where an exceptional degree of isolation has already been demonstrated in the majority of villages. ${ }^{35,36}$ Here, haplogroup $\mathrm{F}$ is not an exception: similar dominant haplotypes can be seen also within haplogroups $\mathrm{U} 2, \mathrm{U} 5$ and in one of the branches of haplogroup T (Figure 1), all probably caused by genetic drift in an isolated population.

The fact that haplogroup $\mathrm{F}$ was subsequently found in the Croatian general mainland population lends a strong credence to the scenario that the source lineages for haplogroup $\mathrm{F}$ in Hvar may be within the continental Croatian and other neighbouring populations. However, we note here that we have not sampled haplogroup F among 56 Slovenians, 200 Albanians and 116 Hungarians (R Villems, personal communication).
There may have been many occasions when haplogroup F could have reached Croatia; several possibilities can be found in recorded history. At the end of the 4th century $\mathrm{AD}$, the Huns left Central Asia and invaded Europe for a short period. As a consequence, this major migration also ended a long period of a predominantly Indo-Aryan nomadic presence in the Steppe Belt, extending from China to Europe with their replacement by Mongoloid and Altaic pastoral nomads. ${ }^{37}$ A few centuries later, the Avars (a Mongol people) established a state on the Pannonian planes (current Hungary and North Croatia). It is historically well documented that Avars formed tribal alliances with Slavs, and, subsequently, partially dissolved into the Slavic populations. ${ }^{38}$ More recently, in the year 1241, Mongols reached the eastern Adriatic through Croatian territory. ${ }^{39}$ Finally, much earlier, there was the ancient Silk Road from China through Central Asia to the Mediterranean that can be considered as another possible route for the introduction haplogroup $\mathrm{F}$ to Europe. Any of these named population movements could have brought haplogroup $\mathrm{F}$ maternal lineages to Croatia. A more extensive admixture of Croatians with Central Asian Turkic or Mongoloid females (eg with Avars) is a less 


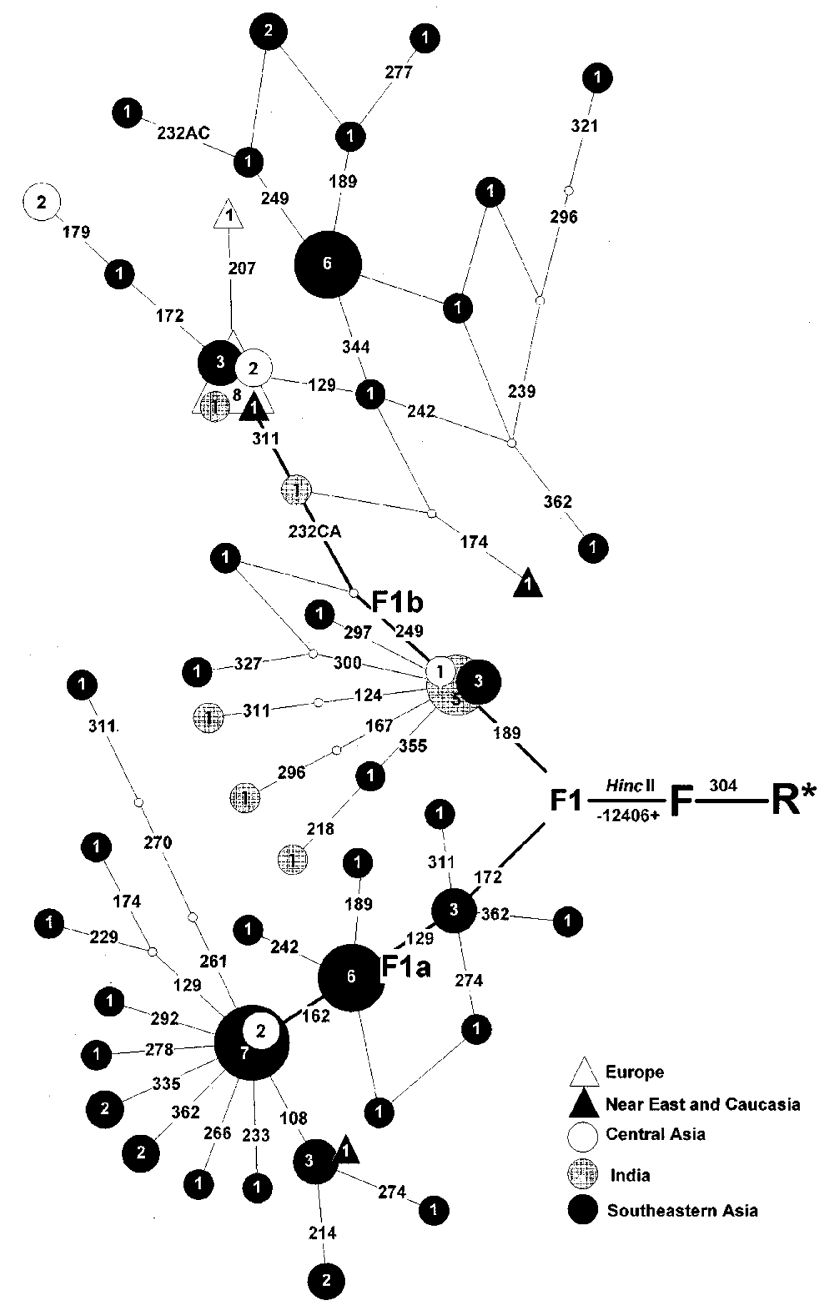

Figure 3 Median-joining network of a subset of human mtDNA haplogroup F: a global distribution of the boughs F1a and F1b of the limb F1 according to the HVS-I sequences. The diagnostic Hincll site at bp 12406 is indicated, but the structure of basal nodes F and F1 are not shown. Haplotype frequencies are shown inside node areas. Mutated mtDNA positions (according to $\mathrm{CRS}^{28,29}$ ) are shown along branches. Mutation type is specified only for transversions. Branches from the root to the basic motifs discussed in the text are shown in bold lines.

likely explanation of our findings because in this case, one would expect to observe the haplogroup $M$ lineages in the Croatian mtDNA pool. The latter haplogroup is almost an order of magnitude more frequent in Central Asians than is haplogroup F. ${ }^{3}$ Since this is not the case, a more specific and narrow founder effect is a more likely explanation.

In summary, the above data show that a maternal lineage, likely arising in the early Upper Palaeolithic period in southeastern Asia, has found a route to Europe and, probably because of random genetic drift, could become a significant component of mtDNA variety in an isolated Adriatic island population. We have also demonstrated that a detailed phylogeographic analysis makes possible the tracing of this lineage back to its possible geographic origin among eastern-central Asian populations. This, in turn, suggests historic and demographic events possibly explaining the presence of mtDNA haplogroup F in Europe.

\section{Acknowledgments}

We are indebted to the Croatian people, in particular inhabitants of the island of Hvar, for their co-operation in performing this study. We thank Ille Hilpus and Jaan Lind for technical assistance. This work was supported by the Ministry of Science and Technology grant no. 01960101 to $P$ Rudan, Estonian Science Foundation grant to $R$ Villems, and the British Council (ALIS), Croatian Ministry of Science (ALIS) and the Wellcome Trust (IRDA) grants to H Campbell and I Rudan. I Rudan was supported by the British Scholarship Trust Fellowship, British Medical Research Council Fellowship and the Scholarship of the University of Edinburgh.

\section{References}

1 Torroni A, Wallace DC: Mitochondrial DNA variation in human populations and implications for detection of mitochondrial DNA mutations of pathological significance. J Bioenerg Biomembr 1994; 26: 261-271.

2 Wallace DC, Shoffner JM, Trounce I et al: Mitochondrial DNA mutations in human degenerative diseases and aging. Biochim Biophys Acta 1995; 1271: $141-151$.

3 Comas D, Calafell F, Mateu E et al: Trading genes along the Silk Road: mtDNA sequences and the origin of Central Asian populations. Am J Hum Genet 1998; 63: 1824-1838.

4 Torroni A, Miller JA, Moore LG et al: Mitochondrial DNA analysis in Tibet: implications for the origin of the Tibetan population and its adaptation to high altitude. Am J Phys Anthropol 1994; 93: 189-199.

5 Torroni A, Lott MT, Cabell MF, Chen YS, Lavergne L, Wallace DC. mtDNA and the origin of Caucasians: identification of ancient Caucasian-specific haplogroups, one of which is prone to a recurrent somatic duplication in the D-loop region. Am J Hum Genet 1994; 55: 760-776.

6 Torroni A, Huoponen K, Francalacci P et al: Classification of European mtDNAs from an analysis of three European populations. Genetics 1996; 44: 1835-1850.

7 Torroni A, Bandelt HJ, D'Urbano L et al: mtDNA analysis reveals a major late Paleolithic population expansion from southwestern to northeastern Europe. Am J Hum Genet 1998; 62: $1137-1152$.

8 Richards M, Corte-Real H, Forster $\mathrm{P}$ et al: Paleolithic and Neolithic lineages in the European mitochondrial gene pool. Am J Hum Genet 1996; 59: $185-203$.

9 Richards MB, Macaulay VA, Bandelt HJ, Sykes BC: Phylogeography of mitochondrial DNA in western Europe. Ann Hum Genet 1998; 62: 241-260.

10 Macaulay V, Richards M, Hickey E et al: The emerging tree of West Eurasian mtDNAs: a synthesis of control-region sequences and RFLPs. Am J Hum Genet 1999; 64: 232 -249.

11 Metspalu E, Kivisild T, Kaldma K et al: The Trans-Caucasus and the expansion of the Caucasoid-specific human mtDNA lineages; in: Deka R, Papiha S (eds): Genomic diversity: Applications in human population genetics. New York, Kluwer Academic/Plenum Publishers, 1999, pp 121-134. 
12 Tambets K, Kivisild T, Metspalu E et al: The topology of the maternal lineages of the Anatolian and Trans-Caucasus populations and the peopling of Europe: some preliminary considerations; in Renfrew C, Boyle K (eds): Archaeogenetics: DNA and the population prehistory of Europe. Cambridge, The McDonald Institute for Archaeological Research, 2000, pp 219-235.

13 Horai S, Murayama K, Hayasaka K et al: mtDNA polymorphism in East Asian populations, with special reference to the peopling of Japan. Am J Hum Genet 1996; 59: 579-590.

14 Nishimaki Y, Sato K, Fang L, Ma M, Hasekura H, Boettcher B: Sequence polymorphism in the mtDNA HV1 region in Japanese and Chinese. Legal Med 1999; 1: 238 - 249.

15 Tolk HV, Pericic M, Barac L et al: mtDNA haplogroups in the populations of Croatian Adriatic islands. Coll Antropol 2000; 24 $267-279$.

16 Ballinger SW, Schurr TG, Torroni A et al: Southeast Asian mitochondrial DNA analysis reveals genetic continuity of ancient mongoloid migrations. Genetics 1992; 130: 139-152.

17 Kolman CJ, Sambuughin N, Bermingham E. Mitochondrial DNA analysis of Mongolian populations and implications for the origin of new world founders. Genetics 1996; 142: $1321-1334$.

18 Pfeiffer H, Steighner R, Fisher R, Mornstad H, Yoon CL, Holland MM: Mitochondrial DNA extraction and typing from isolated dentin - experimental evaluation in a Korean population. Int J Legal Med 1998; 111: 309-313.

19 Lutz S, Weisser HJ, Heizmann J, Pollak S: Location and frequency of polymorphic positions in the mtDNA control region of individuals from Germany. Int J Legal Med 1998; 111: $67-77$.

20 Pfeiffer H, Brinkmann B, Huhne J et al: Expanding the forensic German mitochondrial DNA control region database: genetic diversity as a function of sample size and microgeography. Int $J$ Legal Med 1999; 112: 291-298.

21 Richards M, Macaulay V, Hickey E et al: Tracing European founder lineages in the Near Eastern mtDNA pool. Am J Hum Genet 2000; 67: $1251-1276$

22 Helgason A, Sigurdarðottir S, Gulcher JR, Ward R, Stefansson K: mtDNA and the origin of the Icelanders: deciphering signals of recent population history. Am J Hum Genet 2000; 66: 999-1016.

23 Helgason A, Hickey E, Goodacre S et al: mtDNA and the Islands of the North Atlantic: Estimating the Proportions of Norse and Gaelic Ancestry. Am J Hum Genet 2001; 68: 723 - 737.

24 Kivisild T, Bamshad MJ, Kaldma K et al: Deep common ancestry of Indian and western-Eurasian mitochondrial DNA lineages. Curr Biol 1999; 9: 1331-1334

25 Vigilant L, Stoneking M, Harpending H, Hawkes K, Wilson AC: African populations and the evolution of human mitochondrial DNA. Science 1991; 253: $1503-1507$.
26 Betty DJ, Chin-Atkins AN, Croft L, Sraml M, Easteal S: Multiple independent origins of the COII/tRNA(Lys) intergenic 9-bp mtDNA deletion in aboriginal Australians. Am J Hum Genet 1996; 58: 428 - 433 .

27 Torroni A, Richards M, Macaulay V et al: mtDNA haplogroups and frequency patterns in Europe. Am J Hum Genet 2000; 66: $1173-1177$

28 Anderson S, Bankier AT, Barrell BG et al: Sequence and organization of the human mitochondrial genome. Nature 1981; 290: 457-465.

29 Andrews RM, Kubacka I, Chinnery PF, Lightowlers RN, Turnbull $\mathrm{DM}$, Howell N: Reanalysis and revision of the Cambridge reference sequence for human mitochondrial DNA. Nat Genet 1999; 23: 147.

30 Bandelt HJ, Forster P, Rohl A: Median-joining networks for inferring intraspecific phylogenies. Mol Biol Evol 1999; 16: 37 48.

31 Forster P, Harding R, Torroni A, Bandelt HJ: Origin and evolution of Native American mtDNA variation: a reappraisal. Am J Hum Genet 1996; 59: 935 -945.

32 Belledi M, Poloni ES, Casalotti R et al: Maternal and paternal lineages in Albania and the genetic structure of Indo-European populations. Eur J Hum Genet 2000; 8: 480 - 486.

33 Derenko MV, Shields GF: Mitochondrial DNA sequence diversity in three North Asian Aboriginal population groups. Mol Biol 1997; 31: $665-669$.

34 Schurr TG, Sukernik RI, Starikovskaya YB, Wallace DC: Mitochondrial DNA variation in Koryaks and Itel'men: population replacement in the Okhotsk Sea-Bering Sea region during the Neolithic. Am J Phys Anthropol 1999; 108: 1-39.

35 Rudan P, Finka B, Janicijevic B et al (eds): Anthropological Investigations of Eastern Adriatic - Hvar Island, Croatia. Zagreb, Croatian Anthropological Society, 1990 (in Croatian).

36 Rudan I, Campbell H, Rudan P: Genetic epidemiological studies of Eastern Adriatic Island Isolates, Croatia: Objectives and Strategies. Coll Antropol 1999; 23: 531-546.

37 Garasanin M: The Balkan peninsula on South-East Europe during the Neolithic; in De Laet SJ, Dani AH, Lorenzo JL, Nunoo RB (eds): History of humanity. Vol 1. Prehistory and Beginnings of civilization. Paris and London, UNESCO and Routledge, 1994, pp 207-223.

38 Moravcsik G, Jenkins RJH (eds): Constantine Porphyrogenitus, De Administrando Imperio. Baltimore, Dumbarton Oaks Publishing Service, 1993, p. 143.

39 Sirotkovic J (ed): Encyclopaedia of Yugoslavia. Zagreb, JLZ "Miroslav Krleža", 1989, pp 684-741. 